\title{
Regulatory landscape of the Hox transcriptome
}

\author{
ANA CASACA ${ }^{\#, 1}$, GABRIEL M. HAUSWIRTH ${ }^{\#, 2}$, HEIDI BILDSOE*,2, MOISÉS MALLO ${ }^{*, 1}$ and EDWINA MCGLINN*,2 \\ ${ }^{1}$ Instituto Gulbenkian de Ciência, Oeiras, Portugal and ${ }^{2} E M B L$ Australia, Australian Regenerative Medicine Institute, \\ Monash University, Clayton, Australia
}

\begin{abstract}
Precise regulation of Hox gene activity is essential to achieve proper control of animal embryonic development and to avoid generation of a variety of malignancies. This is a multilayered process, including complex polycistronic transcription, RNA processing, microRNA repression, long noncoding RNA regulation and sequence-specific translational control, acting together to achieve robust quantitative and qualitative Hox protein output. For many such mechanisms, the Hox cluster gene network has turned out to serve as a paradigmatic model for their study. In this review, we discuss current knowledge of how the different layers of post-transcriptional regulation and the production of a variety of noncoding RNA species control Hox output, and how this shapes formation of developmental systems that are reproducibly patterned by complex Hox networks.
\end{abstract}

KEY WORDS: Hox gene, post-transcriptional regulation, polycistronic, lncRNA, microRNA

\section{Introduction}

Hox genes are key regulators of patterning processes during animal embryonic development, also playing important roles in a variety of physiological and pathological processes in the adult animal. The high conservation in function and sequence across phyla makes Hox genes a central component of the so called 'Evo-Devo gene toolkit'. Indeed, it is thought that changes in their spatio-temporal expression during development are at the core of the mechanisms shaping both the highly conserved anatomical structure within a given species and the morphological diversity observed across different animal phyla.

In almost all bilaterian species, Hoxgenes are organized in clusters, although the number of genes and specific cluster organization varies widely among species (Duboule, 2007). It is thought that the Hox clusters of extant animals originated from a common ancestral single cluster that evolved differently through the various branches of the animal phylogenetic tree (Garcia-Fernàndez, 2005). One of the best studied invertebrate example is Drosophila, where the ancestral cluster was split into two complexes known as the Antennapedia and Bithorax complexes (ANT-C and BX-C respectively). In vertebrates, on the other hand, the ancestral cluster underwent a series of duplications followed by gene loss and compaction to generate a variety of cluster arrangements. Mice, for instance, have 39 Hox genes distributed in four clusters, each containing a unique subset of 13 Hox gene paralogs. Teleost lineages have additional sets of Hox clusters resulting from an additional round of genome duplication. The best studied case is that of the zebrafish that contains seven recognizable Hox clusters.

Although classic studies of Hox gene regulation and activity were mostly centered on the protein-coding genes, it was soon recognized that transcription within the Hox clusters was not limited to those transcriptional units (Lipshitz et al., 1987). The improvement of sequencing capabilities revealed that the portion of noncoding transcripts produced from the Hox clusters is far greater than initially appreciated (Mainguy et al., 2007; Rinn et al., 2007). These studies also showed that the noncoding transcripts, which include both microRNAs (miRNAs) and long noncoding RNA (IncRNA) transcribed in both sense and antisense directions, are produced from the Hox clusters of all species analyzed. Indeed, some of these noncoding elements have been conserved together with the Hox-coding genes throughout evolution, further supporting the common origin of the clusters and revealing evolutionary routes affecting the fate of particular Hox clusters. For instance,

Abbreviations used in this paper: HD, homeodomain; lncRNA, long noncoding RNA; mRNA, messenger RNA; miR, microRNA; miRNA, microRNA; LR, linker region; UTR, untranslated region; ORF, open reading frame; uORF, upstream open reading frame; IRES, internal ribosomal entry site; TSS, transcriptional start site; TIE, translational inhibitory element.

\footnotetext{
*Address correspondence to: Moisés Mallo. Instituto Gulbenkian de Ciência, Rua da Quinta Grande 6, 2780-156 Oeiras, Portugal. Tel: +351-214464624. Fax: +351-214407970. e-mail: mallo@igc.gulbenkian.pt - web: http://www.igc.gulbenkian.pt/mmallo - (iD) https://orcid.org/0000-0000-0000-0000 or

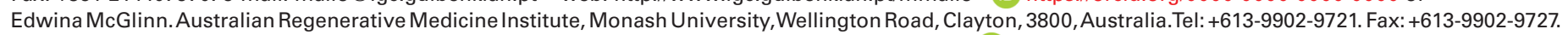
e-mail: edwina.mcglinn@monash.edu - http://www.armi.org.au/about/our-people/edwina-mcglinn - (iD) https://orcid.org/0000-0000-0000-0000
}

\#Note: these authors contributed equally to the work 
the presence of one such element, a lone Hox-embedded miRNA, informs of the transient presence of the missing eighth cluster in the zebrafish genome (Woltering and Durston, 2006).

In this review we will take a closer look at the different RNA species transcribed from Hox clusters, focusing on what can be considered non-canonical transcripts. We will review alternative processing events that occur on Hox gene mRNAs and describe other types of RNA transcripts arising from the Hox clusters, such as miRNAs or IncRNAs. We will also try to summarize current views about the possible impact that these RNA species might have on Hox gene expression and function.

\section{Canonical and non-canonical Hox mRNAs}

While outnumbered by noncoding transcripts, Hox mRNAs are considered the major drivers of Hox function by specifying the amino acid sequence of protein effectors. After transcription, Hox pre-mRNAs undergo important processing events that can diversify their output and regulate quantitative protein production. For instance, alternative splicing can generate mRNA variants coding different protein products. Also, relevant information is encoded in the untranslated regions (UTRs) that include sequences regulating both stability and translational efficiency of the mRNAs. In this section, we will describe some of the regulatory mechanisms acting on Hox mRNAs that bear the potential to impact Hox protein function and expression profiles, thereby expanding the coding capacity of the Hox genome.

\section{Alternative splicing of Hox $m R N A s$ originate protein isoforms}

In contrast to the complex architecture of the Hox clusters, individual Hox genes usually show a remarkably simple organization. With the exception of the presence of microexons in some species,
Hox genes generally contain a single intron, splitting the gene in two exons (Exon I-Intron-Exon II), with the 3' exon coding for the homeodomain (HD). Despite the apparent simplicity of their structure, a series of molecular analyses have shown that Hox genes may undergo complex processes of alternative intron-splicing.

The Drosophila Ubx gene is a well-studied case of alternative splicing. The Ubx transcriptional unit includes, in addition to the canonical Exon I and Exon II, two additional internal microexons (O'Connor et al., 1988; Kornfeld et al., 1989). The presence of these extra microexons, together with two alternative splice donor sites in Exon I, can originate six different Ubx coding sequences (Fig. 1A) (O'Connor et al., 1988; Kornfeld et al., 1989; Reed et al., 2010). Notably, the characterization of Ubx transcript maturation led to the discovery of a new concept of splicing, known as recursive splicing. Recursive splicing represents a mechanism whereby portions of a large intron can be spliced out sequentially, rather than in a single excision step (Hatton et al., 1998; Burnette et al., 1999). While other examples of recursive splicing have been identified in diverse transcriptional units of both invertebrates and vertebrates, in the Hox environment Ubx seems to be the only gene undergoing this process, despite the presence of microexons in other Hox genes.

Canonical RNA splicing events have been shown to generate four different coding sequences from the Drosophila Antp gene, through the inclusion or exclusion of microexons coding for 13 and 4 amino acids, located between the two major exons (Laughon et al., 1986; Stroeher et al., 1986; Bermingham and Scott, 1988). Remarkably, the alternative splicing processes identified in the Antp and Ubx genes introduce variations in the linker region of the protein (LR; the region connecting the hexapeptide motif to the HD), suggesting functional significance, as the LRs contribute actively to the functional properties of Drosophila Hox proteins (Gebelein et al., 2002; Merabet et al., 2003; Reed et al., 2010; Papadopoulos

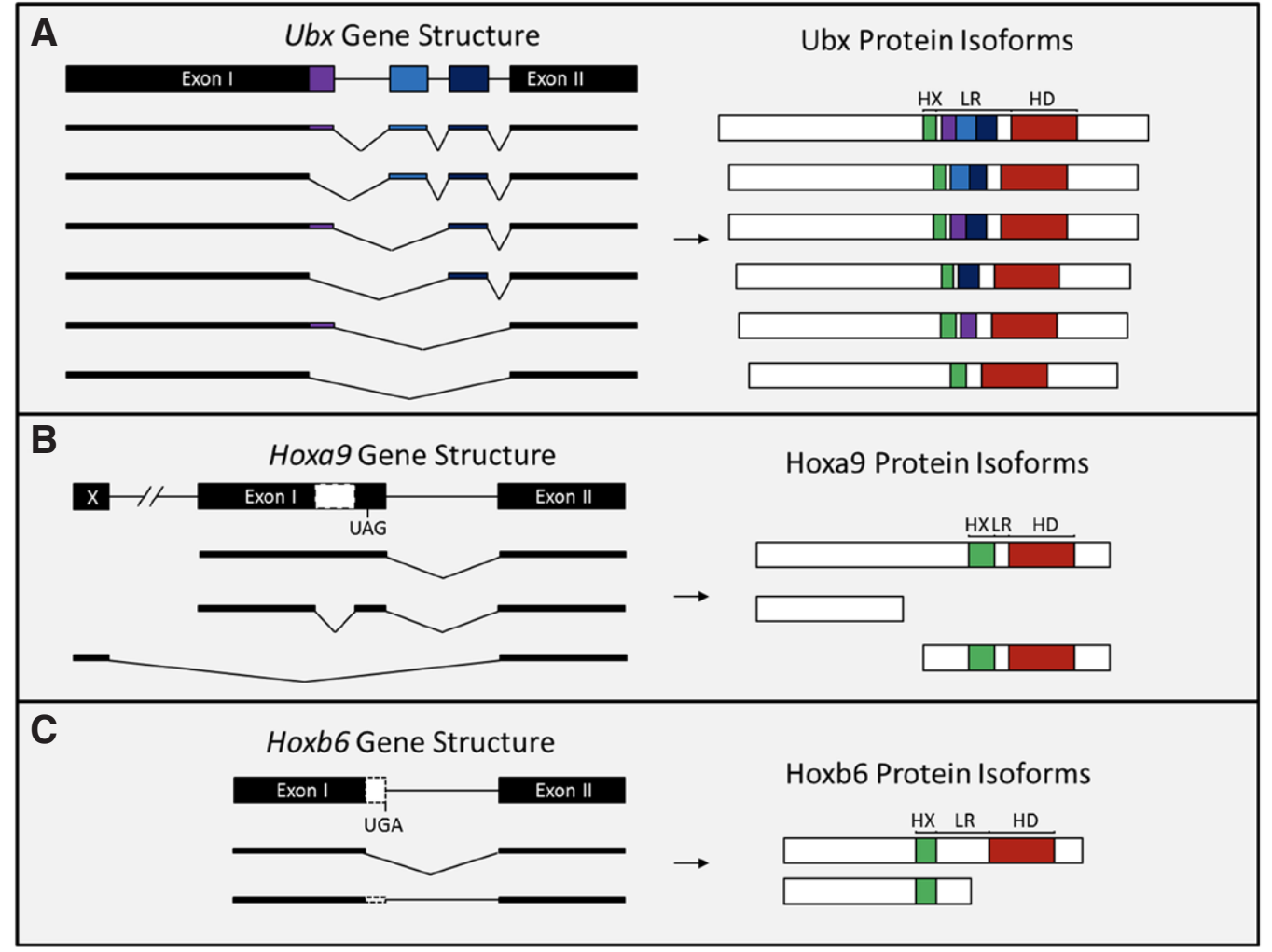

et al., 2011; Navas et al., 2011). Interestingly, it has been reported that these alternatively spliced transcripts might be distributed according to temporally regulated and tissue specific patterns (Lopez and Hogness, 1991; Lopez et al., 1996), further suggesting their functional relevance during Drosophila development.

Alternative splicing events have also been described for other

Fig. 1. Schematics of gene structure of Ubx (A), Hoxa9 (B) and Hoxb6 (C) showing the transcripts splice variants and the corresponding protein isoforms (not to scale). The principal exons are represented in black. Microexons of Ubx are in blue and dark blue and the element spliced out from the recursive splicing event is in purple. Dotted-outline white boxes represent alternatively spliced elements within exons/introns. Stop codons (UAG and UGA) are indicated. HX, hexapeptide; $H X^{\prime}$, modified hexapeptide; $L R$, linker region; $H D$, homeodomain; $X$, exon $X$. 
Drosophila Hox genes, such as $P b, L a b$ and $A b d-B$ (Cribbs et al., 1992; Mlodzik et al., 1988; Kuziora and McGinnis, 1988), although they have been studied in less detail. Altogether, these data clearly suggest that alternative splicing has the potential to play a relevant role in the modulation of Hox protein function.

Alternative splicing events have also been described for vertebrate Hox genes, but they seem to produce isoforms different from those observed in the fly. For instance, despite the essential role that the LR plays in the rib-promoting function of the mouse Hoxb6 protein (Casaca et al., 2016), so far no splice variant affecting the LR size of this, or other vertebrate Hox protein, has been described. Conversely, the most typical splice variants observed for vertebrate Hox genes affect the production of protein products containing or lacking the HD. This is the case of both Hoxa1 and Hoxa9 where a portion of Exon I can undergo an additional splicing event, causing a shift in the reading frame that would produce truncated versions of the Hox proteins lacking the HD (Fig. 1B) (LaRosa and Gudas, 1988; Fujimoto et al., 1998). Importantly, the Hoxa9transcript coding for the truncated protein has been detected in mouse, chicken and human tissues at both embryonic and adult stages (Dintilhac et al., 2004).

A possible role for the truncated Hoxa1 variant was investigated through biochemical approaches (Fernandez and Gudas, 2009). These in vitro studies showed that the truncated Hoxa1 variant interacts directly with the full-length isoform, and indirectly with its cofactor Pbx1, and that this interaction could interfere with the activity of the full-length Hoxa1 during stem cell differentiation. An equivalent role for the truncated form of Hoxa9 was suggested by the observation that it can bind the Hoxa9 cofactor CBP (CREBbinding protein) as efficiently as the full-length Hoxa9 (Dintilhac et al., 2004), which was consistent with a dominant-negative function for the short isoform. The dominant-negative activity of the truncated Hoxa9 protein is, however, not consensual as two other studies proposed that this Hoxa9 isoform can assist the full length protein in its leukemogenic potential (He et al., 2012 and Stadler et al., 2014).

Additional alternatively spliced mRNAs from the Hoxa9gene have been isolated from both mouse and human samples, containing an extra 5' coding exon (Exon X) directly linked to Exon II (Fig. 1B) (Borrow et al., 1996; Kim et al., 1998). Similarly, a non-canonical Hoxa10 mRNA was isolated from E15.5 mouse liver, containing an extra 5' exon (Exon X) linked to the canonical Exon II of the Hoxa10gene. Such mRNAs from both Hoxa9and Hoxa10 containing this alternative exon combination have open reading frames (ORFs) coding for Hox protein variants composed of the HD linked to a small $\mathrm{N}$-terminal region. Whether these proteins are indeed synthesized, as well as their possible functional roles, remain to be investigated. In this regard, we have previously shown that a mutant Hoxa10 lacking most of its $\mathrm{N}$-terminal region is unable to block rib formation in the mouse axial skeleton (Guerreiro et al., 2012), which contrasts with the strong rib-repressing properties of the full-length protein (Carapuço et al., 2005).

Other studies have suggested that Hox protein variants lacking the HD might also exist, but resulting from a mechanism distinct from the ones described above. In particular, truncated proteins from HOXA1 and Hoxb6 would originate not from an extra splicing event, but rather from the unspliced variant of the mRNA, still containing the intron (Chariot et al., 1995; Shen et al., 1991). The identification of unspliced Hoxb6 transcripts at levels that can be detected by Northern blotting or RNAse protection assays indicated that a considerable part of the original transcript might not be immediately spliced. Furthermore, these unspliced transcripts are distributed according to specific spatiotemporal expression patterns in both embryonic tissues and adult organs of mouse and human origin (Shen et al., 1991; Mathews et al., 1993). The presence of an in frame UGA stop codon in the intron just six nucleotides past the splice junction would result in the production of a truncated protein similar to the $\mathrm{N}$-terminal region of Hoxb6 but lacking the homeodomain (Fig. 1C). Support for the translation of such truncated HOXB6 protein was obtained by Komuves and colleagues (2000) when studying the differentiation of human epidermis. Using two different antibodies, one recognizing both protein isoforms and the other specific for the HD-containing isoform, immunostaining experiments on skin samples indicated that the truncated HOXB6 protein was expressed in the cytoplasm of undifferentiated keratinocytes, while the full-length protein was induced upon differentiation and entered the cell nucleus (Komuves et al., 2000). This supports the hypothesis that alternatively-spliced Hox mRNAs can generate distinct proteins.

While the above-discussed observations seem to indicate that a HOXB6 truncated isoform is indeed synthesized in animal tissues, conclusive evidence for the actual occurrence of isoforms of other Hox proteins is still missing. In particular, the studies evaluating the properties of the different Hox isoforms that we have reviewed here (such as the Hoxa9 and Hoxa1 truncated proteins), were performed in stable cell lines forced to express the truncated proteins using constructs containing the already spliced cDNA (Fernandez and Gudas, 2009; Stadler et al., 2014). In addition, the authors reported some technical problems in identifying Hox proteins other than the full-length (Fernandez and Gudas, 2009), further complicating the interpretation of those experiments. Therefore, additional and more conclusive experimental data concerning the protein products derived from variant mRNAs, as well as the biological contexts where they are synthesized, will be instrumental to clarify the full potential of Hox genes.

\section{Polycistronism increases Hox mRNA diversity}

The Hox cluster architecture, with tandemly organized genes, provides a suitable environment for the production of polycistronic transcripts. The first case of Hox polycistronism was reported almost 30 years ago, with the observation that the mouse Hoxc4, Hoxc5 and Hoxc6 genes may be transcribed as part of a single unit (Simeone et al., 1988). This composite transcript would then be alternatively processed to give rise to three mature mRNAs with common 5'UTRs but containing the ORFs coding for the different Hox proteins.

Over the years, analyses of transcriptional profiling have identified a considerable number of polycistronic RNAs synthesized from the mammalian Hox clusters (Mainguy et al., 2007; Brunskill and Potter, 2012). A well-studied case involves the mouse Hoxa5 locus (Coulombe et al., 2010). During embryonic development, overlapping transcripts are synthesized from this region of the HoxA cluster, due to the use of multiple promoters and distinct splicing events. Importantly, some of the resulting transcripts are bicistronic, containing both the Hoxa6and Hoxa5coding sequences. Experiments in cultured cells showed that translation from this polycistronic transcript was restricted to the Hoxa6 ORF, i.e. the one located closer to the 5' end of the transcript. Since multiple 
translation events seem not be occurring from this specific Hox polycistronic transcript, it might represent an alternative regulatory strategy to control Hox gene transcription, eventually following a mechanism similar to those associated with IncRNAs.

Events of alternative splicing in polycistronic transcripts may also produce hybrid Hox protein-coding sequences. A particular case of such hybrid Hox transcript was described by Benson et al., (1995) who detected a transcript containing the 5' exon of Hoxa10 spliced to the HD-containing exon of the adjacent Hoxa9 gene. Exon sharing was also described for zebrafish with the identification of an exon located far upstream of the hoxb4a locus used by both hoxb4a and hoxb3a genes (Hadrys et al., 2004) to produce distinct transcripts upon being spliced to either hoxb4 or hoxb3 exons (Hadrys et al., 2004; Hadrys et al., 2006). However, translation into the corresponding proteins was not directly analyzed, and thus the relevance of exon sharing between Hox genes is still to be clarified.

There is no evidence of polycistronism in Drosophila, probably due to the widely spaced nature of Hoxgenes within the fly clusters, contrary to the tightly clustered vertebrate Hox genes (Duboule, 2007). Nevertheless, bicistronic Antp/Ubx transcripts have been described in other arthropods, such as crustaceans (Shiga et al., 2006) and myriapods (Janssen and Budd, 2010), which suggests their possible importance in diverse arthropod lineages.

\section{Untranslated regions in the control of Hox protein levels}

A close analysis of published data shows that the patterns of Hox protein expression do not always correlate with the expression of the corresponding mRNAs (Nelson et al., 1996; Brend et al., 2003), suggesting that Hox gene regulation might also occur at the translational level. Some of this regulation relies on specific characteristics of the untranslated regions (UTRs) of their mRNAs, which have been shown to be instrumental in post-transcriptional regulatory processes. 3'UTRs, for instance, are frequent miRNAs targets, involved in the modulation of mRNA stability and protein translation (reviewed in Bartel, 2018; Section 4), suggesting that differential mRNA processing can lead to the formation of 3'UTRs carrying substantially distinct instructions.

The Drosophila Ubx transcripts represent an interesting example of how alternative 3'UTR RNA-processing influences gene regulation. Thomsen and collaborators (2010) observed that during Drosophila development, Ubx mRNAs are polyadenylated at two alternative positions, producing transcripts with different 3'UTRs (short and long isoforms). Remarkably, the transcripts with shorter 3'UTR are less susceptible to miRNAs regulation (Bender 2008; Thomsen et al., 2010) and therefore more stable. Together with the finding that short and long isoforms exhibit distinct spatiotemporal expression patterns during fly development, this clearly suggests an important contribution of 3'UTR processing in the regulation of Ubx gene expression. Moreover, Antp, $A b d-A$ or $A b d-B$ can also generate transcripts with various 3'UTR lengths (O'Connor et al., 1988; Sánchez-Herrero and Crosby, 1988; Celniker et al; 1989), each with a distinct spatiotemporal distribution in the embryo (Thomsen et al., 2010), suggesting that gene regulation by alternative 3'UTRs, might be a general strategy adopted for Drosophila Hox genes.

For mammalian Hox genes, there is no evidence of coordination between polyadenylation and 3'UTR lengthening. However, it has been reported that in general 3'UTRs tend to be longer as embryonic development progresses (Ji et al., 2009). Also, alternative polyadenylation sites were identified in the Hoxa4 and Hoxa7 3'UTRs (Yekta et al., 2008). While some experimental validation is needed, it is tempting to speculate a general regulatory mechanism in Hox genes involving coordination of processes affecting alternative polyadenylation and miRNAs.

5'UTRs can also contain several regulatory elements that affect the translation of transcripts. In general, these consist of a variety of cis-regulatory sequences, including binding sites for regulatory factors, upstream ORFs (uORFs), internal ribosomal entry sites (IRES) or translational inhibitory elements (TIEs) (Xue and Barna, 2015). For this reason, variations in 5'UTRs can also function as important switches to regulate protein translation.

Multiple promoters for a given gene, which is a common theme among Hox genes, can generate transcripts containing the same ORF but different 5'UTR lengths and characteristics. This seems particularly relevant for Hox mRNAs, since their 5'UTRs often contain multiple uORFs, known to interfere with cap-dependent translation (Kozak et al., 2005). The various 5'UTRs may diverge in the number of uORFs, and therefore have differential impact on protein production from their main coding region.

In addition to the canonical cap-dependent translation, protein synthesis from eukaryotic mRNAs can be driven by internal ribosomal entry sites (IRES) in their 5'UTR. IRES were initially described as part of the mechanism of picornaviruses to take control of the cell's translational machinery (Pelletier and Sonenberg, 1988). Shortly after the discovery of this element, studies performed in Drosophila cells and transgenic flies described the occurrence of IRES in the long 5'UTRs of Antp and Ubx (Oh et al., 1992; Ye et al., 1997). Notably, the IRES activities associated with these Hox genes are developmentally regulated (Ye et al., 1997), indicating that translational control may be a strategy adopted by Drosophila to modulate Hox protein production. Unfortunately, the biological relevance or mechanistic details of the Drosophila Hox IRES has so far not been further evaluated.

In the mouse, however, recent data showed that IRES might play important roles in Hox mRNAtranslation. Work from the Barna group led not only to the discovery of IRES in the 5'UTRs of HoxA mRNAs, but also showed that these IRES could enable translation of Hox transcripts in areas where cap-dependent translation was locally inhibited (Xue et al., 2015). It is important to mention that a previous study had proposed a regulatory function for the ribosome in the differential translational control of Hox genes. In particular, it was shown that deficiency in ribosomal protein L38 (RPL38) led to reduced translation of a subset of Hox mRNAs, while global protein synthesis was not perturbed (Kondrashov et al., 2011). These observations provided the basis to explain the patterning defects of mouse mutants for the Rpl38 gene, which resembled those associated with mutations in Hox genes. In addition, they suggested differential requirement of various $\operatorname{Hox}$ transcripts for RPL38 integrity within the ribosome (Kondrashov et al., 2011). Interestingly, Xue et al., (2015) have demonstrated that Rpl38-dependent translation of HoxmRNAs relies on the presence of IRES sequences within their 5'UTRs.

Another important finding from this work was that Hox mRNAs have the ability to inhibit cap-dependent translation in order to favor IRES-mediated translation. This property seems to depend on specific inhibitory sequences known as translational inhibitory elements (TIEs), that have been identified in the 5'UTRs of IRES- 
containing Hox mRNAs. However, the mechanism underlying TIE activity is still unclear. One possibility is suggested by a report showing that 4EHP (mRNA cap-binding elF4E-related protein) contributes to the repression of Hoxb4 mRNA translation by binding to the RNA-binding-protein Prep1 (Villaescusa et al., 2009). Prep1 would act as a bridge linking the 3'UTR of the Hoxb4 mRNA to 4EHP that in turn would bind to the 5' cap structure. Recently, a more general role of 4EHP as translational repressor was reported by showing that it makes part of the miRNA-dependent translational repressor machinery complex promoting the formation of a closed-loop structure that approximates the mRNA3'UTR to the 5' cap, blocking translation (Chapat et al., 2017). Whether Hox TIEs participate in this or a similar mechanism to inhibit cap-dependent mRNA translation, still needs experimental evaluation.

Phua et al.,2011) described the presence of an uncapped Hox mRNA species. These researchers showed that when the Hoxd4 mRNAs is first produced, it can either be capped and spliced, or spliced and then cleaved by the Drosha RNAse, in coordination with the release of a miRNA from the 5' region of the transcript. Quite interestingly, the shorter 5'UTR is not capped, which could hinder the cap-dependent translation of this mRNA. Moreover, contrary to other Hox mRNAs, the 5'UTR of this uncapped transcript does not contain IRES activity. Further experimental analysis may help to elucidate whether Drosha processing represents an additional strategy to regulate Hox gene expression.

\section{Hox-associated long noncoding RNA}

In the last decade, it has become evident that Hox clusters are heavily enriched in long noncoding RNAs (IncRNAs), that is, transcripts of $>200$ nucleotides with no discernable protein-coding potential (Rinn et al., 2007; Sessa et al., 2007; Mainguy et al., 2007; Sasaki et al., 2007; De Kumar et al., 2015). Some of the first IncRNAs were described within the bithoraxoid $(b x d)$ region of Drosophila BX-C (Lipshitz et al., 1987; Sanchez-Herrero and Akam, 1989; Cumberledge etal., 1990). Subsequently, sequencing and in situ hybridization screening have demonstrated pervasive transcription of spatially restricted IncRNAs from both strands of the BX-C cluster (Bae et al., 2002, Petruk et al., 2006; Pease et al., 2013) and emerging evidence of IncRNAs arising from the ANT-C cluster (Pettini and Ronshaugen, 2016). Similarly in vertebrates such as humans and mouse, spliced unannotated transcripts are broadly transcribed from all four Hox clusters (Mainguy et al., 2007, reviewed De Kumar and Krumlauf, 2016), with many of these exhibiting evolutionary conservation suggestive of function. Considerable effort has been made to understand whether this extensive noncoding transcriptional output represents noise associated with clustered loci harbouring strong enhancers, or rather, denotes a mechanism that adds to the regulatory toolbox controlling Hox output. Accumulating evidence, at least at the molecular level, supports the latter hypothesis. In Fig. 2 we summarize the
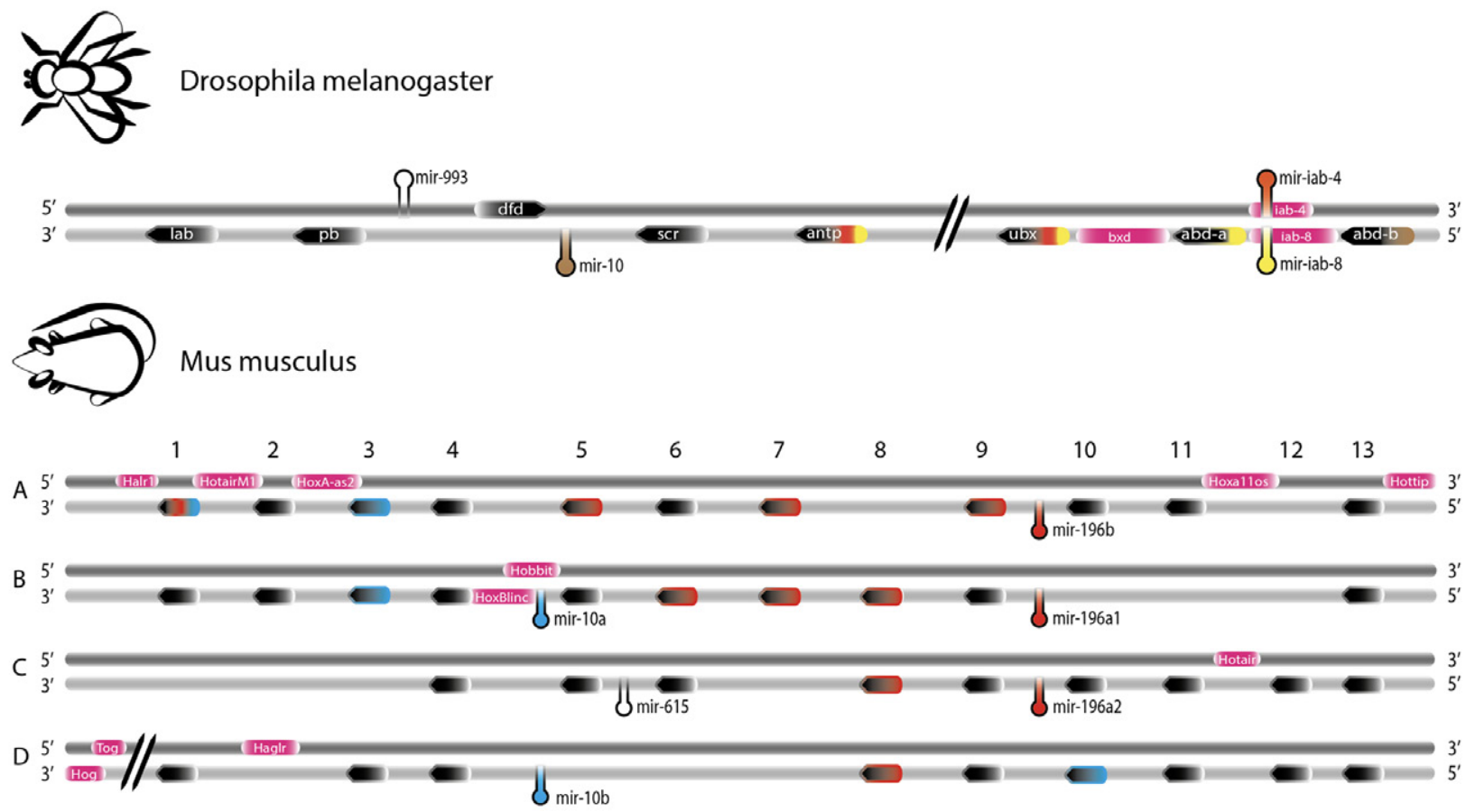

Legend: = Hox gene = $?=$ microRNA

Fig. 2. Schematic illustration of the Drosophila and mouse Hox clusters showing the locations of miRNAs and IncRNAs relative to Hox genes (not to scale). The Drosophila Hox genes are identified by the naming inside the features (black arrows). Mouse Hox genes are identified by their respective numbering and lettering along the axes of the Hox clusters. Depicted are both sense (dark grey) and antisense (light grey) DNA strands. miRNAs and their respective targets are color-coded: Drosophila miR-10 brown, miR-iab-4 red, miR-iab-8 yellow; Mouse miR-10 paralogs blue, miR196 paralogs red. miRNA targets include those currently predicted in Targetscan 7.1 and those with published experimental support. Regions where IncRNAs originate are colored in pink. 
IncRNAs located within or flanking the different Hox loci that have been shown to regulate Hox expression. Various modes of action are associated with these IncRNAs, including consequences relating to the process of transcription of the gene/loci itself, functionality of the noncoding RNA transcript and/or enhancer function. In this section, we will use key examples to demonstrate the breadth of mechanisms utilized by Hox-associated IncRNAs.

\section{LncRNA: modes of action}

Hox-associated IncRNAs have been shown to act in cis or trans, implying that they affect Hox genes from the same or different clusters, respectively. Clear trans-acting examples include the minority of Hox-associated IncRNAs that produce miRNAs (the relevance of which will be further explored in the next section). It is important to note however, that many Hox-embedded miRNAs are produced from long transcripts, such as Drosophila iab-8, which spans at least $120 \mathrm{~Kb}$ (Bae et al., 2002; Bender, 2008). From a cellular perspective, the generation of such long transcripts to merely obtain short miRNA molecules seems an inefficient strategy to adopt. It is therefore possible that miRNA-harbouring IncRNAs may have additional regulatory roles yet to be uncovered. Amore controversial trans-acting example is that of HOTAIR, a IncRNA generated from the intergenic region between $\mathrm{HOXC11}$ and $\mathrm{HOXC12}$, first identified in humans (Rinn et al., 2007) and shown to be conserved in mice (Schorderet and Duboule, 2011) (Fig. 2). Numerous studies demonstrate that HOTAIR/Hotairbinds to the Polycomb repressive complex 2 (PRC2) in cells from distal anatomical regions (i.e. foot fibroblasts or tail tip fibroblasts) and also indicate that this IncRNA functions in trans to repress expression of HoxDgenes (Rinn et al., 2007; Khalil et al., 2009; Tsai et al., 2010). Supporting this, Hotair inactivation in mice by generating a $4 \mathrm{~kb}$ genomic deletion led to derepression of HoxD gene expression, minor limb malformations and homeotic transformation of the last lumbar vertebral element (Li et al., 2013), the latter being consistent with the expected phenotype resulting from mild precocious posterior Hox gene activation (Boulet and Capecchi, 2002). The conclusions from this study have recently been challenged. Using the same Hotair deletion mouse mutant on an outbred background, and performing genomic analyses on embryonic tissue instead of tail tip fibroblasts, the authors did not observe the same molecular or morphological outcomes (Amandio et al., 2016), indicating that Hotair does not regulate lumbo-sacral patterning, nor HoxD suppression in trans. Therefore, Hotair appears to have, at best, a relatively minor role in early embryonic development, and the function of Hotair as a trans repressor of HoxD expression remains debated.

Many cis-acting Hox-associated IncRNAs have been reported in both vertebrates and invertebrates. The Drosophila sense-transcribed $b x d$ IncRNA has been shown to repress Ubx expression, likely by transcriptional interference (Petruk et al., 2006; Pease et al., 2013). However, loss of bxd expression by promoter inversion did not result in overt phenotypic alterations (Pease et al., 2013), a rather surprising finding given the complex array of alternatively spliced IncRNAs produced from the locus. In the mouse, four antisense transcripts have been identified initiating either upstream or from within the first exon of Hoxa11 (Hoxa11as-a and Hoxa11as-b, respectively) (Hsieh-Lie et al., 1995; Potter and Branford, 1998; Kherdjemil et al., 2016). Loss of Hoxa11as- $b$ expression led to an expansion of Hoxa11 sense transcription into the distal part (autopod) of the developing mouse limb (Kherdjemil et al., 2016), a region normally devoid of Hoxa11 expression (Hsieh-Lie et al., 1995). Intriguingly, proximal restriction of Hoxa11 is not observed in the fin buds of teleost and other fish (Sakamoto et al., 2009; Davis et al., 2007, Metscher et al., 2005), which correlates with the reported absence of an enhancer shown to be important for Hoxa11as-b expression (Kherdjemil et al., 2016). Combined with the observation that ectopic distal Hoxa11 expression results in polydactyly, these data suggest that the appearance of Hoxa11as provided a mechanism to restrict Hoxa11 expression from the distal limb, contributing to the emergence of the wrist and ankle joints as well as pentadactyly in tetrapods. Mechanistically, Hoxa11as does not appear to act via sense-antisense pairing of RNA transcripts nor via promoter interference (Kherdjemil et al., 2016; Chau et al., 2002) and thus exactly how this IncRNA exerts its inhibitory effect is yet to be determined.

\section{The role of IncRNAs in chromatin remodelling}

The role of IncRNAs in eliciting chromatin alterations has been well established in both humans and mice (Luo et al., 2016; Quinn and Chang, 2016; Nakagawa et al., 2014 (references herein); Khalil et al., 2009). This can be achieved through the recruitment of histone modifying complexes by the IncRNAs, or by setting up topological domains that facilitate or maintain correct interactions between enhancers and genes. (Wang et al., 2011; Ørom et al., 2010). Within the vertebrate Hoxclusters, Hottip is a good example of a two-tiered mode of action, as both the IncRNA gene locus and the noncoding RNA transcript play a role in chromatin remodelling and recruitment of histone modifiers to facilitate the transcription of neighbouring Hoxgenes. Located upstream of Hoxa13 in both mice (Fig 2; Sasaki et al., 2007; Wang et al., 2011) and humans (Rinn et al., 2007; Wang et al., 2011), Hottip recruits the MLL complex via binding to Wdr5, resulting in the deposition of $\mathrm{H} 3 \mathrm{~K} 4$ me4 marks on 5' HoxA genes and thus keeping them transcriptionally active (Wang et al., 2011; Pradeepa et al., 2017). Additionally, chromatin conformation capture technology identified physical interactions between the Hottip locus and 5' HoxA genes by chromatin looping (Wang et al., 2011). The importance of these interactions is underpinned by the observation that ectopic expression of Hottip RNA does not activate expression of 5' HoxA genes, nor rescues their expression in cells in which the endogenous Hottip had been deleted (Wang et al., 2011). Asimilar dual mechanism was observed for HoxBlinc, a IncRNA regulating the activation of nearby 3' HoxB genes during hematopoietic and cardiac cell lineage specification (Deng et al., 2016). Whether chromosomal looping and transcription of the IncRNA proceed following a specific temporal sequence (i.e. one of them preceding the other), or if both occur concomitantly is currently not known.

An enhancer-like function has been demonstrated for a particular transcriptional start site (TSS) shared by Hog and Tog, two divergent IncRNAs flanking the HoxD cluster (Delpretti et al., 2013). These IncRNAs are exclusively transcribed in the developing cecum and are required for correct activation of specific HoxD genes that pattern this region (Delpretti et al., 2013). This includes proper temporal activation of Hoxd4 to Hoxd11 genes while keeping Hoxd12 and Hoxd13 silent. At least eight enhancers have been identified in the gene desert spanning the telomeric region including the TSS of Hog and Tog, which physically interact with the HoxD genes, in particular Hoxd4 and $d 11$ (Delpretti et al., 2013). These interactions were lost upon inversion of the HoxD cluster and led 
to decreased Hox gene expression, indicating that changing the distance between HoxD genes and the region around Hog and Tog can modify chromatin topology, thereby affecting the activation of the Hox genes. This is underpinned by the ectopic activation of Hoxd12 and $d 13$ in the inversion mutant, suggesting that the changed chromatin microarchitecture now allows Hoxd12 and $d 13$ to interact with activating enhancers and induce their expression (Delpretti et al., 2013). Whether Hog/Tog transcripts are purely a by-product of this physical interaction or are actively involved in setting up the chromatin interaction and looping remains to been addressed.

\section{Competing endogenous RNA}

Finally, emerging data indicates that some IncRNAs might function as miRNA sponges, i.e. competing endogenous RNAs (ceRNAs). Indeed, the Hox-associated IncRNAs HOTAIR and HOTTIP have been implicated as sponges for several miRNAs in various cancers (Luan et al., 2017, Ma et al., 2017 Sun et al., 2017 and Liu et al., 2014), but their function as sponges to regulate Hox gene expression during embryonic development remains to be explored.

Together, accumulating data have shown that IncRNAs are multifaceted molecules working within different layers of Hoxgene regulation. The evolutionary conservation of many Hox-associated IncRNAs from human to mouse (De Kumar and Krumlauf, 2016), suggests functional importance. However, while robust changes in Hox expression have clearly been associated with IncRNAs, much work is still required to evaluate their relative functional relevance in developmental outputs reliant on Hox networks.

\section{Hox-embedded miRNAs shaping Hox cluster output}

MicroRNAs are found in all annotated bilaterian Hox clusters. These short noncoding RNAs act to repress gene expression posttranscriptionally, by deploying the RNA-induced silencing complex to target transcripts in a sequence-dependent manner (reviewed in Bartel, 2018). Hox-embedded miRNAs have a plethora of target transcripts, however, it is clear that across species, Hox genes themselves are present and often enriched within target gene lists (Yekta et al., 2008). Moreover, there is now ample evidence that the function of Hox-embedded miRNAs is essential for a wide range of developmental processes and aberrant in numerous pathological states. In this section, we review the evolution, expression and functional assessment of Hox-embedded miRNAs.

\section{Evolutionary acquisition of Hox-embedded miRNAs}

MicroRNAs have continually been acquired within Hox-clusters over the course of evolution (reviewed in Heimberg and McGlinn, 2012). Drosophila Hox clusters house four miRNAs; miR-10, miR993, miR-iab-4 and miR-iab-8(Fig. 2). miR-10 is common to almost all bilaterian animals, likely arising soon after the cnidarian-bilaterian split and expanding throughout the lineages. This expansion includes the protostome-specific miR-993, a miR-10 family member. In most arthropods, miR-iab-4 and miR-iab-8 are located between abd-A and Abd-B(Aravin etal., 2003; Miura etal., 2011; Ronshaugen et al., 2005). These miRNAs are transcribed bidirectionally, miR$i a b-8$ representing the antisense transcript of $m i R-i a b-4$, with all four mature miRNAs generated from this locus being highly conserved (Miura et al., 2011; Ronshaugen et al., 2005). Murine Hox clusters house six miRNAs; miR-10a, miR-10b, miR-196a1, miR-196a2,
miR-196b and miR-615 (Fig. 2). The genomic position of miR-10, between Hox4 and Hox5 orthologues, has been conserved from fly to mouse. miR-196 arose at the base of chordates and urochordates, while miR-615 is conserved across eutherian mammals. As a general statement, once miRNAs have been acquired within Hox clusters, they are often fixed in the genome, consistent with what has been observed for miRNAs more broadly (Sempere et al., 2006; Wheeler et al., 2009). Moreover, when comparing Hoxembedded miRNA acquisition across a range of vertebrate and invertebrate species (reviewed in Heimberg and McGlinn, 2012), it becomes apparent that the positioning of miRNAs relative to the Hox genes may not be random (Yekta et al., 2008). For example, vertebrate miR-196 occupies a similar, though not syntenic, position to miR-iab4/8 in arthropods. Perhaps more strikingly, miR-10 has been duplicated in the basal chordate Amphioxus, with two additional $m i R-10$ copies located at similar positions occupied by miR-615and miR-196in vertebrates (Campo-Paysaa et al., 2011). A similar duplication and positioning of $m i R-10$ in the evolutionarily distant Capitella telata (Wheeler et al., 2009) supports the view that the genomic position of Hox-embedded miRNAs is important.

\section{Regulated expression of Hox-embedded miRNAs}

In the vertebrate Hox clusters, ample evidence suggests cotranscription of Hox-embedded miRNAs with neighboring $\mathrm{Hox}$ genes. Transcripts containing Hoxb4 and miR-10a or Hoxd4 and miR-10b have been identified in mouse cell lines and in human datasets (Phua et al., 2011; Mainguy etal., 2007), while in zebrafish, miR-10c was identified as a polycistronic transcript together with HoxB3a, originating close to the HoxB5a transcriptional start site (Woltering and Durston, 2008). Additionally, miR-10a expression was also shown to be under the control of a proximal promoter during smooth muscle differentiation in mouse (Huang et al., 2010), although its relevance in other tissues remains unexplored. Notably, the spatio-temporal expression of miR-10a recapitulates the pattern of Hoxb4 during mouse development, in agreement with co-transcriptional expression (Mansfield et al., 2004; For a detailed description of all Hox-embedded miRNA expression patterns, see Mansfield and McGlinn, 2012). For miR-196, there is evidence indicating both polycistronic transcription with neighboring Hox genes (Mainguy et al., 2007) as well as individual transcription starting from an autonomous promoter (Fantini et al., 2015). Which of the two mechanisms represents the major form of miR-196transcription remains unexplored. Certainly however, reporter gene expression driven from individual miR-196a paralog loci is consistent with their collinear activation relative to adjacent Hox9/10 paralogs (Wong et al., 2015), with clear differences in the timing of miR-196a1 and miR-196a2 activation reflecting differences in individual cluster dynamics. miR-615, genomically positioned within the Hoxc5 intron, is assumed to be co-expressed with Hoxc5 in a single transcript. Nonetheless, integrated sequencing data indicates the existence of a miR-615 autonomous promoter located within the coding sequence of Hoxc5 (Quah and Holland, 2015). Evidence exists for both concordant and discordant expression between the host gene and the miRNA, supporting both intron processing and independent transcription in the generation of $m i R-615$. The spatial expression pattern of miR-615 during mouse development is yet to be assessed, although whole-body RNA-seq data indicates that miR-615expression increases throughout mouse embryonic development and is sustained in newborns (Quah and Holland, 2015). 
Unlike vertebrates, Drosophila Hox miRNAs do not seem to be co-transcribed with Hox genes but rather, they are part of long noncoding transcripts. $m i R-10$, for instance, originates from a 7.5 kb polyadenylated transcript (Lemons et al., 2012). Alternative splicing of the primary miRNA transcript has been observed, producing identical mature miRNAs, with an underlying regulatory function yet unknown (Qian et al., 2011). miR-iab-4/8 stem from within long sense and antisense transcripts (iab-4 and iab-8; Bender, 2008; Tyler et al., 2008, Lemons et al., 2012). Different splice isoforms of iab-8 have been detected, exclusively expressed in embryos and adult male flies, eg. male-specific abdominal (Graveley et al., 2011). For both miR-iab-4and miR-iab-8, the $5 p$ arm represents the dominant mature miRNA (Aravin et al., 2003; Bender, 2008; Ruby et al., 2007; Stark et al., 2008; Tyler et al., 2008). The posterior expression patterns of mir-iab-4 and miR-iab-8during development are in register with their genomic positioning, though interestingly, the two miRNAs exhibit no spatial overlap (Bender, 2008; Ronshaugen et al., 2005; Stark et al., 2008; Tyler et al., 2008; Garaulet et al., 2014). This mutual exclusion established at the boundary of abdominal segment precursors of $A 7$ and $A 8$ may result from cross-repressive mechanisms such as transcriptional interference or mature miRNA annealing (Stark et al., 2008).

Post-transcriptional processing of primary miRNAtranscripts can be regulated at multiple steps, resulting in diversification of mature miRNA transcripts within and between species. This is particularly evident for the miR-10 family where both the 3p-and 5p-arms are processed to maturity and expressed in different ratios across species, an event known as arm switching (Landgraf et al., 2007; Lim et al., 2003; Ruby et al., 2007; Stark et al., 2007; Wheeler et al., 2009; Griffiths-Jones et al., 2011). Seed shifting and RNA editing are additional processing mechanisms that generate variety in mature miR-10 species born from a single transcript (Marco et al., 2010; Wheeler et al., 2009).

\section{Functional assessment of Hox-embedded miRNAs}

The genomic positioning of Hox-embedded miRNAs becomes particularly relevant when considering their predicted Hox targets (Yekta et al., 2008; Woltering and Durston, 2008). In vertebrates, the predicted Hox-targets are either biased (miR-10) or exclusively (miR-196) positioned more 3' (proximal) than the miRNA (Fig. 2). In Drosophila, the same can be observed for miR-iab-4/8, though miR-10 predicted Hox targets are biased more 5' (distal) relative to the miRNA (Fig. 2). Given the intrinsic collinear expression pattern of Hox-clusters genes along the anterior-to-posterior (A-P) axis, this suggests a complex spatio-temporal interplay between the miRNAs and their Hox targets with examples of both overlapping and non-overlapping miRNA-target expression patterns observed, and a function in A-P patterning predicted.

Despite predictions, there is little evidence for a strong developmental function for miR-10 across species. Predicted miR-10 target binding sites in Ubx and Abd-B are evolutionarily conserved across Drosophilids suggesting functionality, howevergain-of-function approaches did not demonstrate significant targeting in vivo(Lemons et al., 2012). Moreover, miR-10 locus deletion in Drosophila does not change the levels or spatial pattern of Abd-B protein, though phenotypic characterisation was not presented for this line (Lemons et al., 2012). In vertebrates such as zebrafish, miR-10 synergises with HoxB4a in the molecular repression of hoxB1a and hoxB3a in vivo (Woltering and Durston, 2008), demonstrating a coordinated, co-transcribed, system that represses an anterior Hox program. However, miR-10 gain-of-function resulted in relatively minor neural patterning defects and miR-10 loss-of-function phenotypes were not apparent (Woltering and Durston, 2008). In mouse, genetic deletion of miR-10a has been characterised in the context of disease, with enhanced susceptibility to intestinal neoplasia demonstrated (Stadthagen et al., 2013). The generation of miR10a/b compound mouse knockouts awaits.

In contrast, Drosophila exhibits a stage-specific, essential, requirement for miR-iab4/8 in regulating Hox output, both at the molecular and phenotypic level. At embryonic stages, efficient posterior repression of Ubx and Abd-A requires minimal contribution from miR-iab4/8, consistent with the lack of overt A-P patterning defects observed in mutant flies (Bender, 2008). Here, the action of posterior Hox gene Abd-B dominates, at least in the repression of Ubx. In the larval central nervous system however, the dominant mode of repression transitions to a miRNA-dependent one (Garaulet et al., 2014), with significant phenotypic defects arising. These include sterility (Bender, 2008) and self-righting behavioural defects (Picao-Osorio et al., 2015), downstream of altered Hox repression in separate motor neuron populations (Garaulet et al., 2014; Picao-Osorio et al., 2015). A likely explanation for this stage-specific repression of Hox targets by miR-iab4/8 is the elegant avoidance strategy described in Section 2, whereby dynamically regulated 3'UTR processing initially precludes many miRNA binding sites from the Hox transcript, with subsequent incorporation as development proceeds (Thomsen et al., 2010). However, overexpression of exogenous miR-iab-4 was capable of transforming halteres to wings (Ronshaugen et al., 2005), a classic early Ubx loss of function phenotype, reinforcing that miRNA-target cellular coexpression and/or levels of the miRNA are also critical parameters. Together, these data demonstrate a critical, albeit later than anticipated, role for miR-iab4/8 in controlling functional Hox output. It is interesting to note that Drosophila is a long germ insect where segments arise simultaneously, in contrast to insects such as the red flour beetle Tribolium castaneum, where segmentation happens in a posterior growth zone. As such, it would be interesting to assess whether Hox-embedded miRNAs exhibit a more prominent early A-P patterning role in such species.

Analysis of vertebrate miR-196 has provided the clearest evidence to date for a classic homeotic functioning Hox-embedded miRNA. The miR-196 paralogs form a genomic posterior boundary for Hox genes known to pattern the thoracic region across vertebrates (Yekta et al., 2004), and importantly, the majority of predicted Hox targets lie within this thoracic-forming region. Hoxb8 has been extensively characterised as a miR-196 target, being a unique example in animals of miRNA-directed endonucleolytic target cleavage (Mansfield et al., 2004; Yekta et al., 2004). Consistent with predictions that miR-196 may establish or reinforce posterior Hox boundaries, over-expression and knockdown studies have shown important roles for miR-196 in clearing unwanted Hoxb8 in the developing neural tube and hindlimb (Asli and Kessel, 2010; Hornstein et al., 2005). Additionally, evidence exists for a function of miR-196 within the endogenous Hox target expression domain (McGlinn et al., 2009). Our lab has generated the first complete allelic deletion series for the three miR-196 paralogs in mouse (Wong et al., 2015). This allowed us to perform an unbiased molecular characterisation, revealing that 7 of the 10 predicted miR-196 Hox targets are statistically upregulated following loss 
of miR-196 function at a time-point relevant to the generation of thoracic and lumbar vertebrae (Note: some target predictions have changed in the latest version of Targetscan (Agarwal et al., 2015)). Compound knockout of miR-196 paralogs demonstrated a dose-dependent, non-redundant, role for miR-196 in restricting the number of thoracic elements (Wong et al., 2015). Surprisingly, we also observe a role in restricting the total number of vertebral elements, a phenotype difficult to reconcile with previous Hox literature, though a phenotype consistent with morpholino knockdown of miR-196 in zebrafish (He et al., 2011a/b). Whether this latter phenotype arises due to the observed global posterior shift in Hox code (Wong et al., 2015) and thus delayed activation of "terminator" Hox13 paralogs, or whether miR-196 acts on additional signalling pathways in this context remains to be elucidated. The recent observation that 5' posterior Hox genes directly activate miR-196b transcription in vivo (Fantini et al., 2015) highlights miRNA activity as a novel mechanism whereby a posterior Hox protein represses the activity of a more anterior Hox program (ie. posterior prevalence).

miR-615 has no current obvious link in regulating Hox output during development, though interestingly, both miR-615 and the product of its host gene Hoxc5 were found to repress the telomerase subunit hTERT during cellular differentiation (Yan et al., 2018). This provided another example of a coordinated, co-transcribed, system whereby a Hox protein and a Hox-embedded miRNA repress gene function at different levels.

\section{Concluding remarks}

Over the years, Hox research has significantly focused on the transcriptional regulation of Hox genes, more specifically their conventional Hox coding transcripts, and how the resulting proteins control developmental and pathogenic processes. However, emerging data shows that Hox clusters exhibit remarkable transcriptional complexity, in such a way that one genomic sequence can be incorporated into distinct types of transcripts, either coding or noncoding, sense or antisense. This, together with multiple RNA processing mechanisms, results in a highly diverse Hox transcriptome, including alternatively spliced mRNAs, multifunctional IncRNAs and miRNAs targeting multiple genes. Clearly, the production of these RNA species from the Hox clusters is not a byproduct of the complex transcriptional activity occurring within a rather unconventional chromosomal region packed with genes that should be produced according to very precise spatial and temporal patterns. Just the opposite, the association of distinct transcriptomic profiles with specific biological processes, together with the functional characteristics of these various transcripts indicate that they must be an integral component of the mechanisms guiding proper production of Hox proteins (or variants of those), most likely the main ultimate effectors of Hox function. The study of those transcripts, and particularly their functional relevance, has been complicated by the scarcity of methods allowing efficient interference with the normal activity of those gene products in relevant biological contexts. The emergence of new gene editing technologies, together with the fast improvement of high throughput methods and the refinement of bioinformatic predictive and analytic capabilities, will help in evaluating the real dimension and impact this complex transcriptome has on the activities regulated from the Hox clusters.

\section{Acknowledgements}

A.C. is supported by postdoctoral fellowship SFRH/BPD/89500/2012 from the Fundação para a Ciência e a Tecnologia. G.M.H. is supported by an Australian Government Research Training Program (RTP) Scholarship. M.M. is supported by the Fundação para a Ciência e a Tecnologia, grant PTDC/BEX-BID/0899/2014 and by Santa Casa da Misericordia de Lisboa, grant SCML-MC-60-2014. E.M. is supported by National Health and Medical Research Council Project Grant APP1051792 and Australian Research Council Discovery Project DP180102157. The Australian Regenerative Medicine Institute is supported by grants from the State Government of Victoria and the Australian Government.

\section{References}

AGARWALV, BELLGW, NAMJ-W, BARTELDP (2015). Predicting effective microRNA target sites in mammalian mRNAs. eLife 4.

AMÂNDIO AR, NECSULEA A, JOYE E, MASCREZ B, DUBOULE D (2016). Hotair Is Dispensible for Mouse Development. PLOS Genetics 12.

ARAVINAA, LAGOS-QUINTANAM, YALCINA, ZAVOLAN M, MARKSD, SNYDER B, GAASTERLAND T, MEYER J, TUSCHL T (2003). The Small RNA Profile during Drosophila melanogaster Development. Dev Cell 5: 337-350.

ASLI NS, KESSEL M (2010). Spatiotemporally restricted regulation of generic motor neuron programs by miR-196-mediated repression of Hoxb8. Dev Biol 344: 857-868.

BAE E, CALHOUN VC, LEVINE M, LEWISEB, DREWELLRA(2002). Characterization of the intergenic RNA profile at abdominal-A and Abdominal-B in the Drosophila bithorax complex. Proc Natl Acad Sci USA 99: 16847-16852.

BARTEL DP (2018). Metazoan MicroRNAs. Cell 173: 20-51.

BENDERW (2008). MicroRNAs in the Drosophilabithorax complex. Gen Dev22:14-19.

BENSON GV, NGUYEN TH, MAAS RL (1995). The expression pattern of the murine Hoxa-10 gene and the sequence recognition of its homeodomain reveal specific properties of Abdominal B-like genes. Mol Cell Biol 15: 1591-1601.

BERMINGHAM JR, SCOTTMP (1988). Developmentally regulated alternative splicing of transcripts from the Drosophila homeotic gene Antennapedia can produce four different proteins. EMBO J 7: 3211-22.

BORROWJ, SHEARMANAM, STANTON VP, BECHERR, COLLINST, WILLIAMSAJ, DUBÉ I, KATZ F, KWONG YL, MORRIS C, OHYASHIKI K, TOYAMAK, ROWLEY J, HOUSMAN DE (1996). The $\mathrm{t}(7 ; 11)(\mathrm{p} 15 ; \mathrm{p} 15)$ translocation in acute myeloid leukaemia fuses the genes for nucleoporin NUP96 and class I homeoprotein HOXA9. Nat Genet 12: 159-167.

BOULETAM, CAPECCHI MR (2002). Duplication of the Hoxd11 Gene Causes Alterations in the Axial and Appendicular Skeleton of the Mouse. Dev Biol 249: 96-107.

BREND T, GILTHORPE J, SUMMERBELL D, RIGBY PWJ (2003). Multiple levels of transcriptional and post-transcriptional regulation are required to define the domain of Hoxb4 expression. Development 130: 2717-2728.

BRUNSKILL EW, POTTER SS (2012). RNA-Seq defines novel genes, RNA processing patterns and enhancer maps for the early stages of nephrogenesis: Hox supergenes. Dev Biol 368: 4-17.

BURNETTE JM, HATTON AR, LOPEZ AJ (1999). Trans-acting factors required for inclusion of regulated exons in the Ultrabithorax mRNAs of Drosophila melanogaster. Genetics 151: 1517-1529.

CAMPO-PAYSAA F, SEMON M, CAMERON RA, PETERSON KJ, SCHUBERT $M$ (2011). microRNA complements in deuterostomes: origin and evolution of microRNAs. Evol Dev 13: 15-27.

CARAPUÇO M, VINAGRE T, BOBOLA N, MALLO M (2005). Hox genes specify vertebral types in the presomitic mesoderm. Genes Dev 19: 2116-2121.

CASACA A, NOVOA A, MALLO M (2016). Hoxb6 can interfere with somitogenesis in the posterior embryo through a mechanism independent of its rib-promoting activity. Development 143: 437-448.

CELNIKER SE, KEELAN DJ, LEWIS EB (1989). The molecular genetics of the bithorax complex of Drosophila: characterization of the products of the Abdominal-B domain. Genes Dev 3: 1424-1436.

CHAPAT C, JAFARNEJAD SM, MATTA-CAMACHO E, HESKETH GG, GELBART IA ATTIG J, GKOGKAS CG, ALAINT, STERN-GINOSSAR N, FABIAN MR, GINGRAS A-C, DUCHAINE TF, SONENBERG N (2017). Cap-binding protein 4EHP effects 
translation silencing by microRNAs. Proc Natl Acad Sci USA 114: 5425-5430.

CHARIOT A, MOREAU L, SENTERRE G, SOBEL M, CASTRONOVO V (1995). Retinoic Acid Induces Three Newly Cloned HOXA1 Transcripts in MCF7 Breast Cancer Cells. Biochem Biophys Res Commun 215: 713-720.

CHAU YM, PANDO S, TAYLOR HS (2002). HOXA11 Silencing and Endogenous HOXA11 Antisense Ribonucleic Acid in the Uterine Endometrium. J Clin Endocrin Metab 87: 2674-2680.

COULOMBE Y, LEMIEUX M, MOREAU J, AUBIN J, JOKSIMOVIC M, BÉRUBÉSIMARD FA, TABARIÈS S, BOUCHERAT O, GUILLOU F, LAROCHELLE C, TUGGLE CK, JEANNOTTE L (2010). Multiple Promoters and Alternative Splicing: Hoxa5 Transcriptional Complexity in the Mouse Embryo. PLOS ONE 5.

CRIBBS DL, PULTZ M a, JOHNSON D, MAZZULLA M, KAUFMAN TC (1992). Structural complexity and evolutionary conservation of the Drosophila homeotic gene proboscipedia. EMBO J 11: 1437-49.

CUMBERLEDGE S, ZARATZIAN A, SAKONJU S (1990).Characterization of two RNAs transcribed from the cis-regulatory region of the abd-A domain within the Drosophila bithorax complex. Proc Natl Acad Sci USA 87:3259-63

DAVIS MC, DAHN RD, SHUBIN NH (2007). An autopodial-like pattern of Hox expression of a basal actinopterygian fish. Nature 447:473-6.

DE KUMAR B, KRUMLAUF R (2016). HOXs and lincRNAs: Two sides of the same coin. Sci Adv 2.

DE KUMAR B, PARRISH ME, SLAUGHTER BD, UNRUH JR, GOGOL M, SEIDEL C, PAULSON A, LI H, GAUDENZ K, PEAK A, MCDOWELL W, FLEHARTY B, AHN Y, LIN C, SMITH E, SHILATIFARD A, KRUMLAUF R (2015). Analysis of dynamic changes in retinoid-induced transcription and epigenetic profiles of murine Hox clusters in ES cells. Genome Res 25: 1229-1243.

DELPRETTI S, MONTAVON T, LELEU M, JOYE E, TZIKA A, MILINKOVITCH M, DUBOULE D (2013). Multiple Enhancers Regulate Hoxd Genes and the Hotdog LncRNA during Cecum Budding. Cell Rep 5: 137-150.

DENG C, LI Y, ZHOU L, CHO J, PATEL B, TERADA N, LI Y, BUNGERT J, QIU Y, HUANG S (2016). HoxBlinc RNA Recruits Set1/MLL Complexes to Activate Hox Gene Expression Patterns and Mesoderm Lineage Development. Cell Rep 14: 103-114.

DINTILHAC A, BIHAN R, GUERRIER D, DESCHAMPS S, PELLERIN I (2004). A conserved non-homeodomain Hoxa9 isoform interacting with CBP is co-expressed with the 'typical' Hoxa9 protein during embryogenesis. Gene Expr Patterns 4:215-222.

DUBOULE D (2007). The rise and fall of Hox gene clusters. Development 134: 2549-2560.

FANTINI S, SALSI V, VITOBELLO A, RIJLI FM, ZAPPAVIGNA V (2015). MicroRNA$196 \mathrm{~b}$ is transcribed from an autonomous promoter and is directly regulated by Cdx2 and by posterior Hox proteins during embryogenesis. Biochimica et Biophysica Acta (BBA) - Gene Regulatory Mechanisms 1849: 1066-1080.

FERNANDEZ CC, GUDAS LJ (2009). The truncated Hoxa1 protein interacts with Hoxa1 and Pbx1 in stem cells. J Cell Biochem 106: 427-443.

FUJIMOTO S, ARAKI K, CHISAKA O, ARAKI M, TAKAGI K, YAMAMURA KI (1998). Analysis of the murine Hoxa-9 cDNA: an alternatively spliced transcript encodes a truncated protein lacking the homeodomain. Gene 209: 77-85.

GARAULET DL, CASTELLANOS MC, BEJARANO F, SANFILIPPO P, TYLER DM, ALLAN DW, SÁNCHEZ-HERRERO E, LAI EC (2014). Homeotic Function of Drosophila Bithorax-Complex miRNAs Mediates Fertility by Restricting Multiple Hox Genes and TALE Cofactors in the CNS. Dev Cell 29: 635-648.

GARCIA-FERNÀNDEZ J (2005). Hox, ParaHox, ProtoHox: facts and guesses. Heredity 94: 145-152.

GEBELEIN B, CULI J, RYOO HD, ZHANG W, MANN RS (2002). Specificity of Distalless Repression and Limb Primordia Development by Abdominal Hox Proteins. Dev Cell 3: 487-498.

GRAVELEY BR, BROOKS AN, CARLSON JW, DUFF MO, LANDOLIN JM, YANG L, ARTIERI CG, BAREN MJV, BOLEY N, BOOTH BW, et al., (2011). The developmental transcriptome of Drosophila melanogaster. Nature 471: 473-479.

GRIFFITHS-JONES S, HUI JHL, MARCO A, RONSHAUGEN M (2011). MicroRNA evolution by arm switching. EMBO Rep 12: 172-177.

GUERREIRO I, CASACA A, NUNES A, MONTEIRO S, NOVOA A, FERREIRA RB, BOM J, MALLO M (2012). Regulatory role for a conserved motif adjacent to the homeodomain of Hox10 proteins. Development 139: 2703-2710.

HADRYS T, PRINCE V, HUNTER M, BAKER R, RINKWITZ S (2004). Comparative genomic analysis of vertebrate Hox3 and Hox4 genes. J Exp Zoo/302B: 147-164.

HADRYS T, PUNNAMOOTTIL B, PIEPER M, KIKUTA H, PEZERON G, BECKERTS, PRINCE V, BAKERR, RINKWITZS (2006). Conserved co-regulation and promoter sharing of hoxb3a and hoxb4a in zebrafish. Dev Biol 297: 26-43.

HATTON AR, SUBRAMANIAM V, LOPEZ A (1998). Generation of Alternative UItrabithorax Isoforms and Stepwise Removal of a Large Intron by Resplicing at Exon-Exon Junctions. Mol Cell 2: 787-796.

HE M, CHEN P, ARNOVITZ S, LI Y, HUANG H, NEILLY MB, WEI M, ROWLEY JD, CHEN J, LI Z (2012). Two isoforms of HOXA9 function differently but work synergistically in human MLL-rearranged leukemia. Blood Cells, Mol Dis 49: 102-106.

HE X, YAN Y-L, DELAURIER A, POSTLETHWAIT JH (2011a). Observation of miRNA Gene Expression in Zebrafish Embryos by In situ Hybridization to MicroRNA Primary Transcripts. Zebrafish 8: 1-8.

HE X, YAN Y-L, EBERHART JK, HERPIN A, WAGNER TU, SCHARTL M, POSTLETHWAIT JH (2011b). miR-196 regulates axial patterning and pectoral appendage initiation. Dev Biol 357: 463-477.

HEIMBERG A, MCGLINN E (2012). Building a Robust A-P Axis. Curr Genomics 13: 278-288.

HORNSTEIN E, MANSFIELD JH, YEKTA S, HU JK-H, HARFE BD, MCMANUS MT, BASKERVILLE S, BARTEL DP, TABIN CJ (2005). The microRNA miR-196 acts upstream of Hoxb8 and Shh in limb development. Nature 438: 671-674.

HSIEH-LIE HM, WITTE DP, WEINSTEIN M, BRANFORD W, LI H, SMALLK, POTTER SS (1995). Hoxa11 structure, extensive antisense transcriptiona, and function in male and female fertility. Development 121:1373-1385.

HUANG H, XIE C, SUN X, RITCHIE RP, ZHANG J, CHEN YE (2010). miR-10a Contributes to Retinoid Acid-induced Smooth Muscle Cell Differentiation. J. Biol. Chem. 285: 9383-9389.

JANSSEN R, BUDD GE (2010). Gene expression suggests conserved aspects of Hox gene regulation in arthropods and provides additional support for monophyletic Myriapoda. EvoDevo 1: 1-11.

JI Z, LEE JY, PAN Z, JIANG B, TIAN B (2009). Progressive lengthening of 3' untranslated regions of mRNAs by alternative polyadenylation during mouse embryonic development. Proc Natl Acad Sci USA 106: 7028-7033.

KHALILAM, GUTTMANM, HUARTEM, GARBERM, RAJA, MORALESDR, THOMAS K, PRESSERA, BERNSTEIN BE, OUDENAARDEN AV, REGEV A, LANDER ES, RINN JL (2009). Many human large intergenic noncoding RNAs associate with chromatin-modifying complexes and affect gene expression. Proc Natl Acad Sci USA 106: 11667-11672.

KHERDJEMIL Y, LALONDE RL, SHETH R, DUMOUCHEL A, MARTINO GD, PINEAULT KM, WELLIK DM, STADLER HS, AKIMENKO M-A, KMITA M (2016). Evolution of Hoxa11 regulation in vertebrates is linked to the pentadactyl state. Nature 539: 89-92.

KIM MH, CHANG HH, SHIN C, CHO M, PARK D, PARK HW (1998). Genomic structure and sequence analysis of human HOXA-9. DNA Cell Biol 17: 407-414.

KONDRASHOV N, PUSICA, STUMPF CR, SHIMIZU K, HSIEHAC, XUE S, ISHIJIMA J, SHIROISHI T, BARNAM (2011). Ribosome-Mediated Specificity in Hox mRNA Translation and Vertebrate Tissue Patterning. Cell 145: 383-397.

KORNFELD K, SAINT RB, BEACHY PA, HARTE PJ, PEATTIE DA, HOGNESS DS (1989). Structure and expression of a family of Ultrabithorax mRNAs generated by alternative splicing and polyadenylation in Drosophila. Genes Dev 3: 243-258.

KÖMÜVES LG, SHEN WF, KWONG A, STELNICKI E, ROZENFELD S, ODA Y BLINK A, KRISHNAN K, LAU B, MAURO T, LARGMAN C (2000). Changes in HOXB6 homeodomain protein structure and localization during human epidermal development and differentiation. Dev Dyn 218: 636-647.

KUZIORA MA, MCGINNIS W (1988). Different transcripts of the Drosophila Abd-B gene correlate with distinct genetic sub-functions. EMBO J 7: 3233-3244.

LANDGRAF P, RUSU M, SHERIDAN R, SEWER A, IOVINO N, ARAVIN A, PFEFFER S, RICE A, KAMPHORST AO, LANDTHALER M, add. (2007). A Mammalian microRNA Expression Atlas Based on Small RNA Library Sequencing. Cell 129: 1401-1414.

LAROSA GJ, GUDAS LJ (1988). Early retinoic acid-induced F9 teratocarcinoma stem cell gene ERA-1: alternate splicing creates transcripts for a homeobox-containing protein and one lacking the homeobox. Mol Cell Biol 8: 3906-3917.

LAUGHON A, BOULET AM, BERMINGHAM JR, LAYMON RA, SCOTT MP (1986). Structure of transcripts from the homeotic Antennapedia gene of Drosophila melanogaster: two promoters control the major protein-coding region. Mol Cell 
Biol 6: 4676-4689.

LEMONS D, PARÉ A, MCGINNIS W (2012). Three Drosophila Hox Complex microRNAs Do Not Have Major Effects on Expression of Evolutionarily Conserved Hox Gene Targets during Embryogenesis. PLOS ONE 7.

LI L, LIU B, WAPINSKI OL, TSAI M-C, QU K, ZHANG J, CARLSON JC, LIN M, FANG F, GUPTA RA, HELMS JA, CHANG HY (2013). Targeted Disruption of Hotair Leads to Homeotic Transformation and Gene Derepression. Cell Rep 5: 3-12.

LIM LP, GLASNER ME, YEKTA S, BURGE CB, BARTEL DP (2003). Vertebrate MicroRNA Genes. Science 299: 1540-1540.

LIPSHITZ HD, PEATTIE DA, HOGNESS DS (1987). Novel transcripts from the Ultrabithorax domain of the bithorax complex. Gen Dev 1: 307-322.

LIU X-H, SUN M, NIE F-Q, GE Y-B, ZHANG E-B, YIN D-D, KONG R, XIA R, LU K-H, LI J-H, DE W, WANG K-M, WANG Z-X (2014). Lnc RNA HOTAIR function as a competing endogenous RNA to regulate HER2 expression by sponging miR-331$3 p$ in gastric cancer. Mol Cancer 13: 92.

LOPEZ AJ, HOGNESS DS (1991). Immunochemical dissection of the Ultrabithorax homeoprotein family in Drosophila melanogaster. Proc Natl Acad Sci USA 88: 9924-9928.

LOPEZ AJ, ARTERO RD, PEREZ-ALONSO M (1996). Stage, tissue, and cell specific distribution of alternative Ultrabithorax mRNAs and protein isoforms in the Drosophila embryo. Roux's Arch Dev Biol 205: 450-459.

LUAN W, LI R, LIU L, NI X, SHI Y, XIA Y, WANG J, LU F, XU B (2017). Long noncoding RNA HOTAIR acts as a competing endogenous RNA to promote malignant melanoma progression by sponging miR-152-3p. Oncotarget 8 .

LUO S, LU JY, LIU L, YIN Y, CHEN C, HAN X, WU B, XU R, LIU W, YAN P, SHAO W, LU Z, LI H, NA J, TANG F, WANG J, ZHANG YE, SHEN X (2016). Divergent IncRNAs Regulate Gene Expression and Lineage Differentiation in Pluripotent Cells. Cell Stem Cell 18: 637-652.

MA J, FAN Y, FENG T, CHEN F, XU Z, LI S, LIN Q, HE X, SHI W, LIU Y, CAO X, ZHU B, LIUZ (2017). HOTAIR regulates HK2 expression by binding endogenous miR-125 and $\mathrm{miR}-143$ in oesophageal squamous cell carcinoma progression. Oncotarget8.

MAINGUY G, KOSTER J, WOLTERING J, JANSEN H, DURSTON A (2007). Extensive Polycistronism and Antisense Transcription in the Mammalian Hox Clusters. PLOS ONE 2

MANSFIELD JH, MCGLINN E (2012). Evolution, Expression, and Developmental Function of Hox-Embedded miRNAs. MicroRNAs in Development Curr. Top. Dev. Biol:: 31-57.

MANSFIELD JH, HARFE BD, NISSEN R, OBENAUER J, SRINEEL J, CHAUDHURI A, FARZAN-KASHANI R, ZUKER M, PASQUINELLI AE, RUVKUN G, SHARP PA, TABIN CJ, MCMANUS MT (2004). MicroRNA-responsive 'sensor' transgenes uncover Hox-like and other developmentally regulated patterns of vertebrate microRNA expression. Nature Genetics 36: 1079-1083.

MARCO A, HUI JHL, RONSHAUGEN M, GRIFFITHS-JONES S (2010). Functional shifts in insect microRNA evolution. Genome Biol. Evol. 2: 686-696.

MATHEWS CH, DETMER K, LAWRENCE HJ, LARGMAN C (1993). Expression of the Hox 2.2 homeobox gene in murine embryonic epidermis. Differentiation 52: $177-184$.

MCGLINN E, YEKTA S, MANSFIELD JH, SOUTSCHEK J, BARTEL DP, TABIN CJ (2009). in ovo application of antagomiRs indicates a role for miR-196 in patterning the chick axial skeleton through Hox gene regulation. Proc Natl Acad Sci USA 106: 18610-18615.

MERABET S, KAMBRIS Z, CAPOVILLA M, BÉRENGER H, PRADEL J, GRABA Y (2003). The Hexapeptide and Linker Regions of the AbdA Hox Protein Regulate Its Activating and Repressive Functions. Dev Cell 4: 761-768.

METSCHER BD, TAKAHASHI K, CROW K, AMEMIYA C, NONAKA DF, WAGNER GP (2005). Expression of Hoxa-11 and Hoxa-13 in the pectoral fin of a basal ray-finned fish, Polyodon spathula: implications for the origin of tetrapod limbs. Evol Dev 7: 186-195

MIURA S, NOZAWA M, NEI M (2010). Evolutionary Changes of the Target Sites of Two MicroRNAs Encoded in the Hox Gene Cluster of Drosophila and Other Insect Species. Genome Biology and Evolution 3: 129-139.

MLODZIKM, FJOSEA, GEHRING WJ (1988). Molecular structure and spatial expression of a homeobox gene from the labial region of the Antennapedia-complex. EMBO J 7: 2569-78.

NAKAGAWA S, KAGEYAMA Y (2014). Nuclear IncRNAs as epigenetic regulatorsBeyond skepticism. Biochim Biophys Acta (BBA) - Gene Regulatory Mechanisms
1839: 215-222.

NAVAS LFD, REED H, AKAM M, BARRIO R, ALONSO CR, SANCHEZ-HERRERO $E$ (2011). Integration of RNA processing and expression level control modulates the function of the Drosophila Hox gene Ultrabithorax during adult development. Development 138: 107-116.

NELSON CE, MORGAN BA, BURKE AC, LAUFER E, DIMAMBRO E, MURTAUGH LC, GONZALES E, TESSAROLLO L, PARADA LF, TABIN C (1996). Analysis of Hox gene expression in the chick limb bud. Development 122: 1449-1466.

O'CONNOR MB, BINARI R, PERKINS LA, BENDER W, GEHRING WJ (1988). Alternative RNA products from the Ultrabithorax domain of the bithorax complex. EMBO J 7: 435-445.

OHSK, SCOTT MP, SARNOWP (1992). Homeotic gene Antennapedia mRNAcontains 5 '-noncoding sequences that confer translational initiation by internal ribosome binding. Genes Dev 6: 1643-1653.

PAPADOPOULOS DK, RESENDEZ-PEREZ D, CARDENAS-CHAVEZ DL, VILLANUEVA-SEGURA K, CANALES-DEL-CASTILLO R, FELIX DA, FUNFSCHILLING R, GEHRING WJ (2011). Functional synthetic Antennapedia genes and the dual roles of YPWM motif and linker size in transcriptional activation and repression. Proc Natl Acad Sci USA 108: 11959-11964.

PEASE B, BORGES AC, BENDER W (2013). Noncoding RNAs of the Ultrabithorax Domain of the Drosophila Bithorax Complex. Genetics 195: 1253-1264.

PETRUK S, SEDKOV Y, RILEY KM, HODGSON J, SCHWEISGUTH F, HIROSE S, JAYNES JB, BROCK HW, MAZO A (2006). Transcription of bxd Noncoding RNAs Promoted by Trithorax Represses Ubx in cis by Transcriptional Interference. Cell 127: $1209-1221$

PETTINI T, RONSHAUGEN M (2016). Transvection and pairing of a Drosophila Hox long noncoding RNA in the regulation of Sex combs reduced. bioRxiv.

PHUASLC, SIVAKAMASUNDARI V, SHAOY, CAIX, ZHANG L-F, LUFKINT, FEATHERSTONE M (2011). Nuclear Accumulation of an Uncapped RNA Produced by Drosha Cleavage of a Transcript Encoding miR-10b and HOXD4. PLOS ONE 6 .

PICAO-OSORIO J, JOHNSTON J, LANDGRAF M, BERNI J, ALONSO CR (2015) MicroRNA-encoded behaviour in Drosophila. Science 350: 815-820

POTTERSS, BRANFORD WW (1998). Evolutionary conservation and tissue-specific processing of Hoxa 11 antisense transcripts. Mamm Genome 9: 799-806.

PRADEEPA MM, MCKENNA F, TAYLOR GCA, BENGANI H, GRIMES GR, WOOD AJ, BHATIAS, BICKMORE WA (2017). Psip1/p52 regulates posterior Hoxa genes through activation of IncRNA Hottip. PLOS Genetics 13.

QIAN J, ZHANG Z, LIANG J, GE Q, DUAN X, MA F, LI F (2011). The full-length transcripts and promoter analysis of intergenic microRNAs in Drosophila melanogaster. Genomics 97: 294-303.

QUAH S, HOLLAND PWH (2015). The Hox cluster microRNA miR-615: a case study of intronic microRNA evolution. EvoDevo 6: 1-12.

QUINN JJ, CHANG HY (2016). Unique features of long non-coding RNA biogenesis and function. Nat Rev Genet 17: 47-62.

REED HC, HOARE T, THOMSEN S, WEAVER TA, WHITE RAH, AKAM M, ALONSO CR (2010). Alternative Splicing Modulates Ubx Protein Function in Drosophila melanogaster. Genetics 184: 745-758.

RINN JL, KERTESZ M, WANG JK, SQUAZZO SL, XU X, BRUGMANN SA, GOODNOUGH LH, HELMS JA, FARNHAM PJ, SEGALE, CHANG HY (2007). Functional Demarcation of Active and Silent Chromatin Domains in Human HOX Loci by Noncoding RNAs. Cell 129: 1311-1323.

RONSHAUGEN M, BIEMAR F, PIEL J, LEVINE M, LAI EC (2005). The Drosophila microRNA iab-4 causes a dominant homeotic transformation of halteres to wings. Gen Dev 19: 2947-2952.

RUBY JG, JAN CH, BARTEL DP (2007). Intronic microRNA precursors that bypass Drosha processing. Nature 448: 83-86.

SAKAMOTOK, ONIMARU K, MUNAKATAK, SUDAN, TAMURAM, OCHI H, TANAKA M (2009). Heterochronic Shift in Hox-Mediated Activation of Sonic hedgehog Leads to Morphological Changes during Fin Development. PLOS ONE 4.

SÁNCHEZ-HERRERO E, CROSBY MA (1988). The Abdominal-B gene of Drosophila melanogaster: overlapping transcripts exhibit two different spatial distributions. EMBO J 7: 2163-73.

SASAKI YT, SANO M, KIN T, ASAI K, HIROSE T (2007). Coordinated expression of ncRNAs and HOX mRNAs in the human HOXA locus. Biochem Biophys Res Commun 357: 724-730. 


\section{A. Casaca et al.}

SCHORDERET P, DUBOULE D (2011). Structural and Functional Differences in the Long Non-Coding RNA Hotair in Mouse and Human. PLoS Genetics 7.

SEMPERE LF, COLE CN, MCPEEK MA, PETERSON KJ (2006). The phylogenetic distribution of metazoan microRNAs: insights into evolutionary complexity and constraint. JEZ-B Molec. Dev. Evol. 206B: 575-588.

SESSA L, BREILING A, LAVORGNA G, SILVESTRI L, CASARI G, ORLANDO V (2007). Noncoding RNA synthesis and loss of Polycomb group repression accompanies the colinear activation of the human HOXA cluster. RNA 13: 223-239.

SHEN W-F, DETMER K, SIMONITCH-EASON TA, LAWRENCE H, LARGMAN C (1991). Alternative splicing of the HOX2.2 homeobox gene in human hematopoietic cells and murine embryonic and adult tissues. Nucleic Acids Res 19: 539-545.

SHIGAY, SAGAWAK, TAKAI R, SAKAGUCHI H, YAMAGATA H, HAYASHI S (2006). Transcriptional readthrough of Hox genes Ubx and Antp and their divergent post-transcriptional control during crustacean evolution. Evol Dev 8: 407-414.

SIMEONE A, PANNESE M, ACAMPORAD, D'ESPOSITO M, BONCINELLIE (1988). At least three human homeoboxes on chromosome 12 belong to the same transcription unit. Nucleic Acids Res 16: 5379-5390.

STADLER CR, VEGI N, MULAW MA, EDMAIER KE, RAWAT VPS, DOLNIK A, BULLINGER L, HEILMEIER B, QUINTANILLA-FEND L, SPIEKERMANN K, HIDDEMANN W, DÖHNER K, DÖHNER H, FEURING-BUSKE M, BUSKE C (2014). The leukemogenicity of Hoxa9 depends on alternative splicing. Leukemia 28: 1838-1843.

STADTHAGEN G, TEHLER D, HOYLAND-KROGHSBO NM, WEN J, KROGH A, JENSEN KT (2013) Loss of miR-10a Activates Lpo and Collaborates with Activated Wnt Signaling in Inducing Intestinal Neoplasia in Female Mice. PLoS Genet 9: e1003913.

STARK A, KHERADPOUR P, PARTS L, BRENNECKE J, HODGES E, HANNON GJ, KELLIS M (2007). Systematic discovery and characterization of fly microRNAs using 12 Drosophila genomes. Genome Res 17: 1865-1879.

STARK A, BUSHATI N, JAN CH, KHERADPOUR P, HODGES E, BRENNECKE J, BARTEL DP, COHEN SM, KELLIS M (2008). A single Hox locus in Drosophila produces functional microRNAs from opposite DNA strands. Gen Dev 22: 8-13.

STROEHER VL, JORGENSEN EM, GARBER RL (1986). Multiple transcripts from the Antennapedia gene of Drosophila melanogaster. Mol Cell Biol 6: 4667-4675.

SUN Y, ZHOU Y, BAI Y, WANG Q, BAO J, LUO Y, GUO Y, GUO L (2017). A long non-coding RNA HOTTIP expression is associated with disease progression and predicts outcome in small cell lung cancer patients. Mol Cancer 16.

THOMSEN S, AZZAM G, KASCHULA R, WILLIAMS LS, ALONSO CR (2010). Developmental RNA processing of 3'UTRs in Hox mRNAs as a context-dependent mechanism modulating visibility to microRNAs. Development 137: 2951-2960.

TSAI M-C, MANOR O, WAN Y, MOSAMMAPARAST N, WANG JK, LAN F, SHI Y, SEGAL E, CHANG HY (2010). Long Noncoding RNA as Modular Scaffold of Histone Modification Complexes. Science 329: 689-693.
TYLER DM, OKAMURAK, CHUNG W-J, HAGEN JW, BEREZIKOV E, HANNON GJ, LAI EC (2008). Functionally distinct regulatory RNAs generated by bidirectional transcription and processing of microRNA loci. Gen Dev 22: 26-36.

VILLAESCUSA JC, BURATTI C, PENKOV D, MATHIASEN L, PLANAGUMÀ J, FERRETTI E, BLASI F (2009). Cytoplasmic Prep1 Interacts with 4EHP Inhibiting Hoxb4 Translation. PLOS ONE 4.

WANG KC, YANG YW, LIUB, SANYALA, CORCES-ZIMMERMANR, CHENY, LAJOIE BR, PROTACIO A, FLYNN RA, GUPTA RA, WYSOCKA J, LEI M, DEKKER J, HELMS JA, CHANG HY (2011). A long noncoding RNAmaintains active chromatin to coordinate homeotic gene expression. Nature 472: 120-124.

WHEELER BM, HEIMBERG AM, MOY VN, SPERLING EA, HOLSTEIN TW, HEBER S, PETERSON KJ (2009). The deep evolution of metazoan microRNAs. Evol Dev 11: 50-68.

WOLTERING JM, DURSTON AJ (2008). MiR-10 Represses HoxB1a and HoxB3a in Zebrafish. PLOS ONE 3.

WOLTERING JM, DURSTON AJ (2006). The zebrafish hoxDb cluster has been reduced to a single microRNA. Nature Genet. 38: 601-602.

WONG SFL, AGARWAL V, MANSFIELD JH, DENANSN, SCHWARTZMG, PROSSER HM, POURQUIÉ O, BARTEL DP, TABIN CJ, MCGLINN E (2015). Independent regulation of vertebral number and vertebral identity by microRNA-196 paralogs. Proc Natl Acad Sci USA 112: E4884-E4893.

XUE S, BARNA M (2015). Cis-regulatory RNA elements that regulate specialized ribosome activity. RNA Biol 12: 1083-1087.

XUE S, TIAN S, FUJII K, KLADWANG W, DAS R, BARNA M (2015). RNA regulons in Hox 5' UTRs confer ribosome specificity to gene regulation. Nature 517: 33-38.

YAN T, OOI WF, QAMRA A, CHEUNG A, MA D, SUNDARAM GM, XU C, XING M, POON L, WANG J, et al., (2018). HoxC5 and miR-615-3p target newly evolved genomic regions to repress $h$ TERT and inhibit tumorigenesis. Nat Commun 9: 100.

YE X, FONG P, IIZUKA N, CHOATE D, CAVENER DR (1997). Ultrabithorax and Antennapedia 5' untranslated regions promote developmentally regulated interna translation initiation. Mol Cell Biol 17: 1714-1721.

YEKTA S, SHIH I, BARTEL DP (2004). MicroRNA-Directed Cleavage of HOXB8 mRNA. Science 304: 594-596.

YEKTA S, TABIN CJ, BARTEL DP (2008). MicroRNAs in the Hox network: an apparent link to posterior prevalence. Nat Rev Genet 9: 789-796.

ØROM UA, DERRIEN T, BERINGER M, GUMIREDDY K, GARDINI A, BUSSOTTI G, LAI F, ZYTNICKI M, NOTREDAME C, HUANG Q, GUIGO R, SHIEKHATTAR R (2010). Long Noncoding RNAs with Enhancer-like Function in Human Cells. Cell 143: 46-58. 


\section{Further Related Reading, published previously in the Int. J. Dev. Biol.}

\section{Evolution of the activation domain in a Hox transcription factor}

Ying Liu, Annie Huang, Rebecca M. Booth, Gabriela Geraldo Mendes, Zabeena Merchant, Kathleen S. Matthews and Sarah E. Bondos Int. J. Dev. Biol. (2018) 62: XXXX-XXXX (this issue)

https://doi.org/10.1387/ijdb.180151sb

\section{The road to the vertebral formula}

Moisés Mallo, Tânia Vinagre and Marta Carapuço

Int. J. Dev. Biol. (2009) 53: 1469-1481

https://doi.org/10.1387/ijdb.072276mm

The significance of Hox gene collinearity

Stephen J. Gaunt

Int. J. Dev. Biol. (2015) 59: 159-170

https://doi.org/10.1387/ijdb.150223sg

Synergistic action in P19 pluripotential cells of retinoic acid and Wnt3a on Cdx1 enhancer elements

Stephen J. Gaunt and Yu-Lee Paul

Int. J. Dev. Biol. (2014) 58: 307-314

https://doi.org/10.1387/ijdb.140003sg

The Parahox gene Pdx1 is required to maintain positional identity in the adult foregut Andrew M. Holland, Sonia Garcia, Gaetano Naselli, Raymond J. MacDonald and Leonard C. Harrison

Int. J. Dev. Biol. (2013) 57: 391-398

https://doi.org/10.1387/ijdb.120048ah

Hox collinearity - a new perspective

Antony J. Durston, Hans J. Jansen, Paul In der Rieden and Michiel H.W. Hooiveld Int. J. Dev. Biol. (2011) 55: 899-908

https://doi.org/10.1387/ijdb.113358ad

Origins of $\mathrm{Cdx} 1$ regulatory elements suggest roles in vertebrate evolution Stephen J. Gaunt and Yu-Lee Paul

Int. J. Dev. Biol. (2011) 55: 93-98

https://doi.org/10.1387/ijdb.103252sg

5 yr ISI Impact Factor $(2016)=2.421$
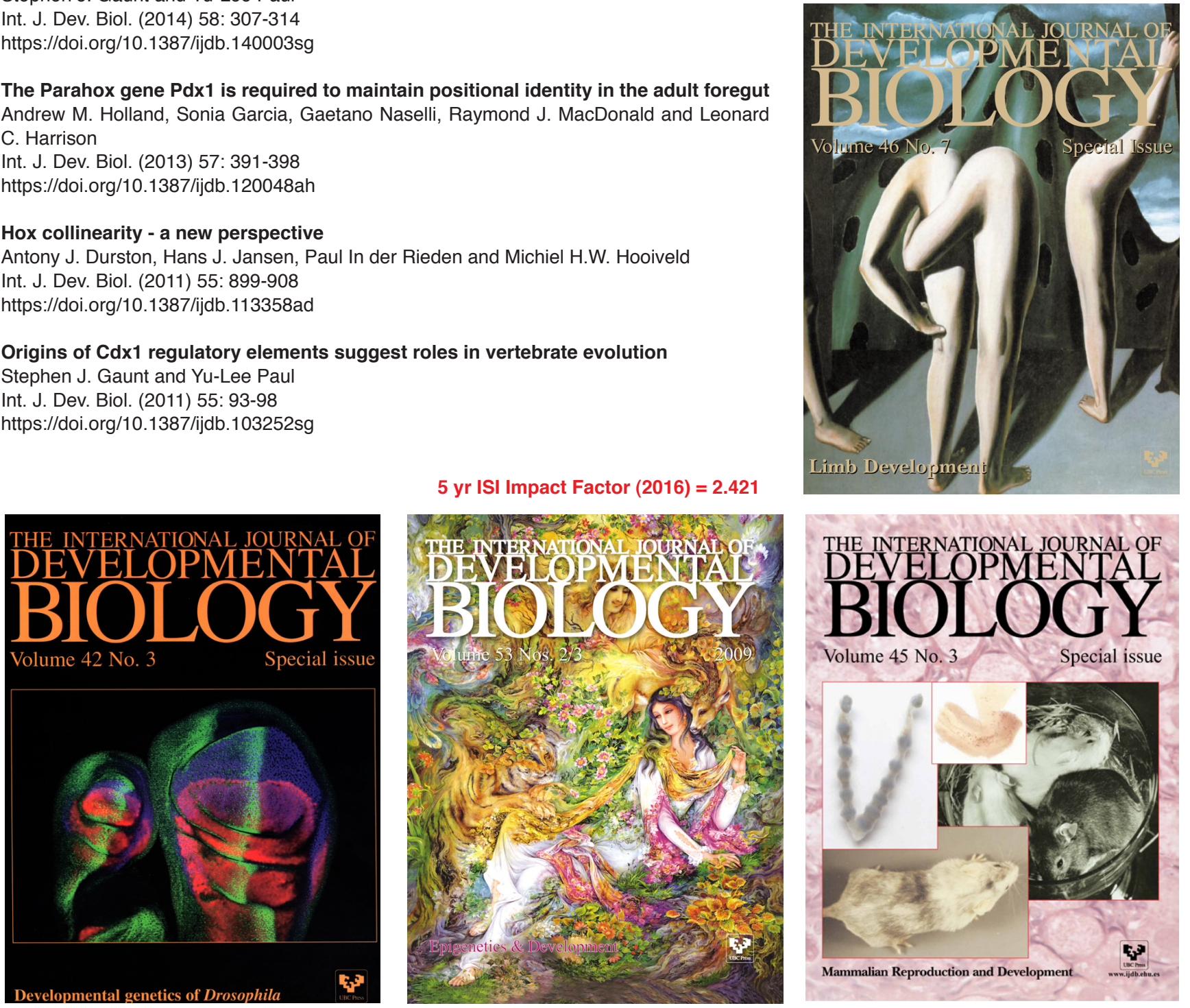